\title{
Pittosporum gatopense
}

\author{
Assessment by: Gemmill, C. et al.
}

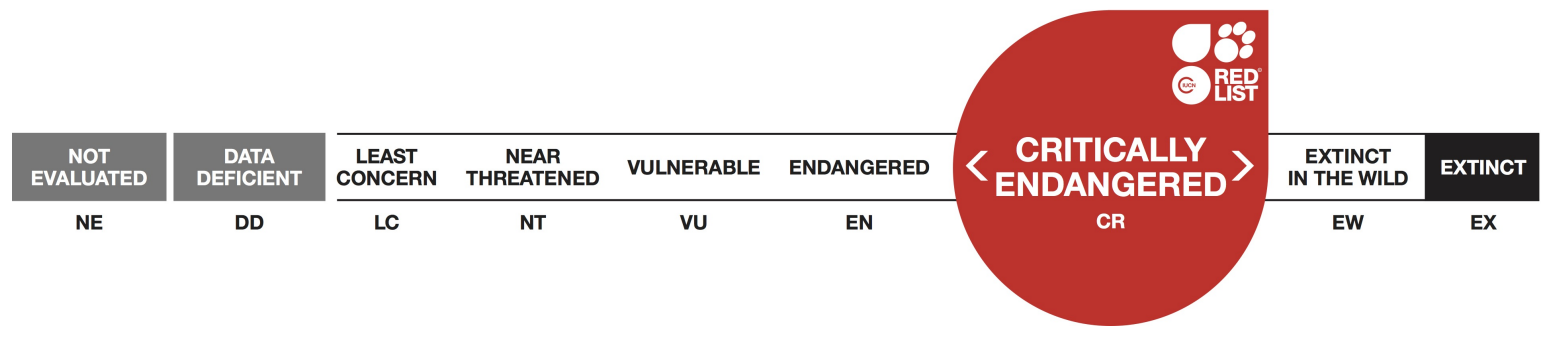

View on www.iucnredlist.org

Short citation: Gemmill, C. et al. 2017. Pittosporum gatopense. The IUCN Red List of Threatened Species 2017: e.T35266A67764057. http://dx.doi.org/10.2305/IUCN.UK.20173.RLTS.T35266A67764057.en [see full citation at end]

Copyright: (C) 2017 International Union for Conservation of Nature and Natural Resources Reproduction of this publication for educational or other non-commercial purposes is authorized without prior written permission from the copyright holder provided the source is fully acknowledged.

Reproduction of this publication for resale, reposting or other commercial purposes is prohibited without prior written permission from the copyright holder. For further details see Terms of Use.

The IUCN Red List of Threatened Species ${ }^{T M}$ is produced and managed by the IUCN Global Species Programme, the IUCN Species Survival Commission (SSC) and The IUCN Red List Partnership. The IUCN Red List Partners are: Arizona State University; BirdLife International; Botanic Gardens Conservation International; Conservation International; NatureServe; Royal Botanic Gardens, Kew; Sapienza University of Rome; Texas A\&M University; and Zoological Society of London.

If you see any errors or have any questions or suggestions on what is shown in this document, please provide us with feedback so that we can correct or extend the information provided. 


\section{Taxonomy}

\begin{tabular}{|c|c|c|c|c|}
\hline Kingdom & Phylum & Class & Order & Family \\
\hline Plantae & Tracheophyta & Magnoliopsida & Rosales & Pittosporaceae \\
\hline
\end{tabular}

Taxon Name: Pittosporum gatopense Guillaumin

\section{Taxonomic Source(s):}

Tirel, Ch. and Veillon, J.-M. 2002. Flore de la Nouvelle-Calédonie, tome 24. Pittosporaceae. Museum d'Histoire Naturelle, Paris.

\section{Assessment Information}

Red List Category \& Criteria: Critically Endangered C2a(i,ii) ver 3.1

Year Published: 2017

Date Assessed: July 24, 2015

\section{Justification:}

Pittosporum gatopense is an endemic tree of New Caledonia restricted to low altitude sclerophyllous coastal forest patches. Characterized by an area of occupancy of $70 \mathrm{~km}^{2}$, an extent of occurrence of 757 $\mathrm{km}^{2}$, a population size estimated to be fewer than 250 mature individuals, $P$. gatopense constitutes a rare species. Last census report of the population found fewer than 50 mature individuals in each subpopulation. Threats to the species include invasive species, bushfire, domestic animal husbandry and urban development, which are resulting in a continuous decline of $P$. gatopense. Using criteria $C, P$. gatopense qualifies for listing as Critically Endangered (CR) C2a(i,ii).

\section{Previously Published Red List Assessments}

2010 - Vulnerable (VU)

http://dx.doi.org/10.2305/IUCN.UK.2010-4.RLTS.T35266A9922819.en

1998 - Endangered (EN)

1998 - Endangered (E)

\section{Geographic Range}

\section{Range Description:}

Pittosporum gatopense is an endemic tree of New Caledonia restricted to the area of Poya to Voh on the west coast.

\section{Country Occurrence:}

Native: New Caledonia 


\section{Distribution Map}

\section{Pittosporum gatopense}
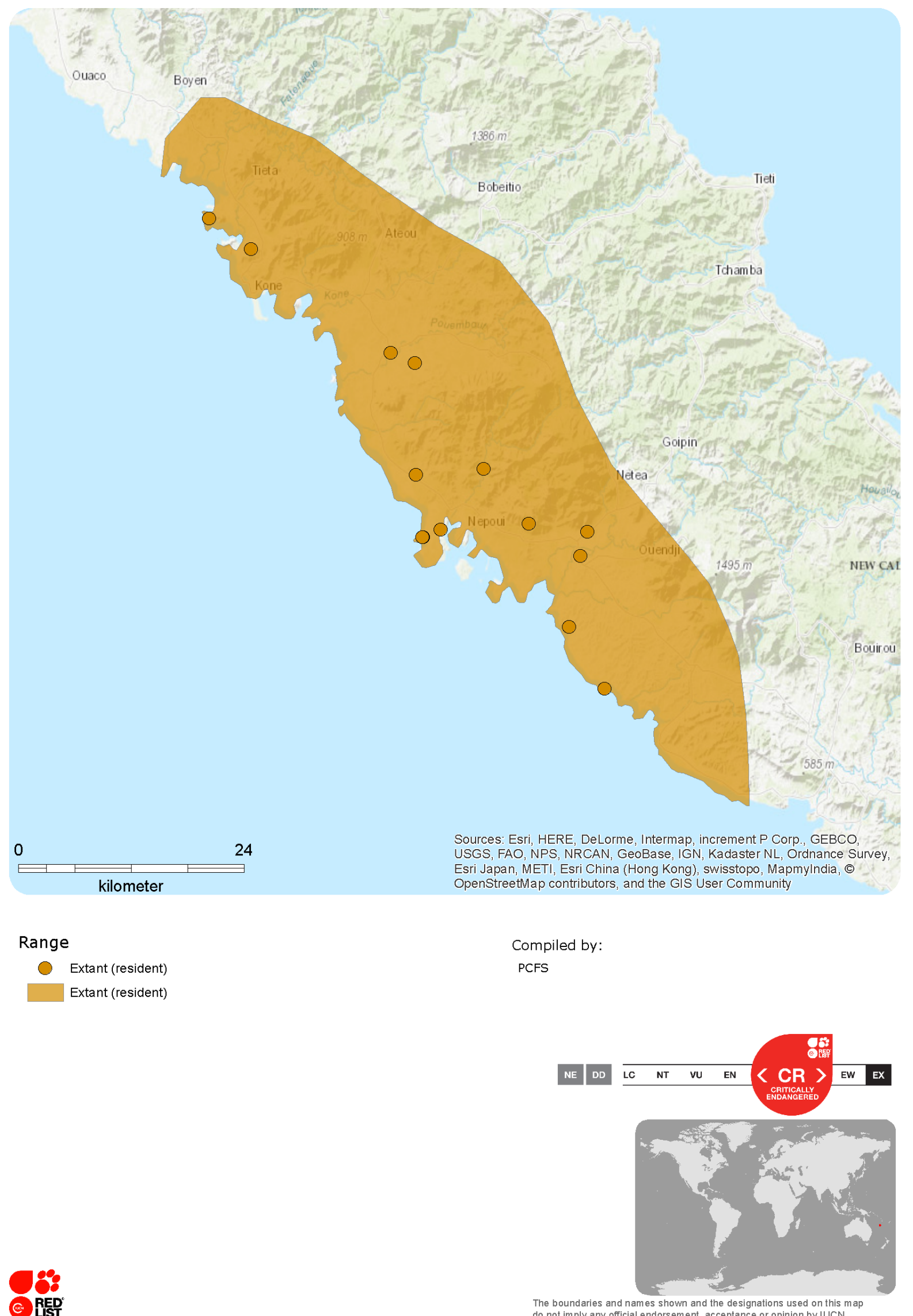


\section{Population}

On the basis of seven known subpopulations and last observations, population size is estimated to be fewer than 250 mature individuals and the largest subpopulation size is estimated to be fewer than 50 mature individuals.

Current Population Trend: Decreasing

\section{Habitat and Ecology (see Appendix for additional information)}

Pittosporum gatopense is restricted to low altitude sclerophyllous forest patches along the coastline on shallow soil calcareous soils and deeper black tropical clay soils.

Systems: Terrestrial

\section{Threats (see Appendix for additional information)}

The main threats are linked to damage and loss of habitat. Sclerophyllous forest are subject to multiple threats such as bushfire, animal husbandry, urbanization and building construction related to the KNS mining project. Animal invasive species constitute a threat for natural regeneration (consumption of fruits by rats). Rusa Deer, now perfectly adapted to New Caledonian habitats, are affecting native plants directly (killing plants by eating bark and seedlings) and indirectly (through habitat degradation). According to the scientific community, dry forest represent only $1 \%$ of its original size in New Caledonia.

\section{Conservation Actions (see Appendix for additional information)}

Protected by legislation in Province Nord and Province Sud, Pittosporum gatopense is monitored by Conservatoire des Espaces Naturels on fenced Népouiri area. A plot, called "zone Jaffré", has been fenced at the initiative of KNS. Field surveys are required at the Moindou locality to confirm if plants still survive here. In order to ensure longevity for this species, wildlife corridors should be maintained between subpopulations to avoid fragmentation. In situ reintroduction associated with monitoring is recommended to stop population decline.

\section{Credits}

Assessor(s): $\quad$ Gemmill, C., Veillon, J.-M., Amice, R., Cazé, H., Dumontet, V., Fleurot, D., Garnier, D., Gâteblé, G., Letocart, I., Letocart, D., Maggia, L. \& Pain, A.

Reviewer(s): $\quad$ Tanguy, V.

Contributor(s): Hequet, $\mathrm{V}$.

Facilitators(s) and Chanfreau, S.

Compiler(s): 


\section{Bibliography}

Bouchet, P., Jaffré, T. and Veillon J.-M. 1995. Plant extinction in New Caledonia: protection of sclerophyll forest urgently needed. Biodiversity \& Conservation 4: 415-428.

Endemia.nc. 2016. Faune et Flore de Nouvelle-Calédonie. Available at: http://www.endemia.nc.

Gomez, C., Mangeas, M., Curt, T., Ibanez, T., Munzinger, J., Dumas, P., Jérémy, A., Despinoy, M. and Hély, C. 2014. Wildfire risk for main vegetation units in a biodiversity hotspot: modeling approach in New

Caledonia, South Pacific. Ecology and Evolution 5(2): 377-390. DOI: 10.1002/ece3.1317.

Hély-Alleaume. 2012. INC : Incendies et biodiversité des éco-systèmes en Nouvelle-Calédonie.

IUCN. 2017. The IUCN Red List of Threatened Species. Version 2017-3. Available at: www.iucnredlist.org. (Accessed: 7 December 2017).

Tirel, Ch. and Veillon, J.-M. 2002. Flore de la Nouvelle-Calédonie, tome 24. Pittosporaceae. Museum d'Histoire Naturelle, Paris.

\section{Citation}

Gemmill, C., Veillon, J.-M., Amice, R., Cazé, H., Dumontet, V., Fleurot, D., Garnier, D., Gâteblé, G., Letocart, I., Letocart, D., Maggia, L. \& Pain, A. 2017. Pittosporum gatopense. The IUCN Red List of Threatened Species 2017: e.T35266A67764057. http://dx.doi.org/10.2305/IUCN.UK.20173.RLTS.T35266A67764057.en

\section{Disclaimer}

To make use of this information, please check the Terms of Use.

\section{External Resources}

For Images and External Links to Additional Information, please see the Red List website. 


\section{Appendix}

\section{Habitats}

(http://www.iucnredlist.org/technical-documents/classification-schemes)

\begin{tabular}{|c|c|c|c|}
\hline Habitat & Season & Suitability & $\begin{array}{l}\text { Major } \\
\text { Importance? }\end{array}$ \\
\hline 1. Forest $->$ 1.5. Forest - Subtropical/Tropical Dry & - & Suitable & - \\
\hline
\end{tabular}

\section{Threats}

(http://www.iucnredlist.org/technical-documents/classification-schemes)

\begin{tabular}{|c|c|c|c|c|}
\hline Threat & Timing & Scope & Severity & Impact Score \\
\hline \multirow{3}{*}{$\begin{array}{l}\text { 1. Residential \& commercial development -> } 1.1 . \\
\text { Housing \& urban areas }\end{array}$} & Ongoing & - & - & - \\
\hline & Stresses: & \multirow{2}{*}{\multicolumn{3}{|c|}{$\begin{array}{l}\text { 1. Ecosystem stresses }->1.1 \text {. Ecosystem conversion } \\
\text { 1. Ecosystem stresses }->1.2 \text {. Ecosystem degradation }\end{array}$}} \\
\hline & & & & \\
\hline \multirow{4}{*}{$\begin{array}{l}\text { 2. Agriculture \& aquaculture }->2.3 \text {. Livestock farming } \\
\& \text { ranching }->2.3 .2 \text {. Small-holder grazing, ranching or } \\
\text { farming }\end{array}$} & Ongoing & - & - & - \\
\hline & Stresses: & \multirow{3}{*}{\multicolumn{3}{|c|}{$\begin{array}{l}\text { 1. Ecosystem stresses }->1.1 \text {. Ecosystem conversion } \\
\text { 1. Ecosystem stresses }->1.2 \text {. Ecosystem degradation } \\
\text { 2. Species Stresses }->2.3 \text {. Indirect species effects }-> \\
\text { 2.3.7. Reduced reproductive success }\end{array}$}} \\
\hline & & & & \\
\hline & & & & \\
\hline \multirow{4}{*}{$\begin{array}{l}\text { 7. Natural system modifications }->7.1 \text {. Fire } \& \text { fire } \\
\text { suppression }->7.1 .1 \text {. Increase in fire } \\
\text { frequency/intensity }\end{array}$} & Ongoing & - & - & - \\
\hline & Stresses: & \multirow{3}{*}{\multicolumn{3}{|c|}{$\begin{array}{l}\text { 1. Ecosystem stresses }->1.1 \text {. Ecosystem conversion } \\
\text { 1. Ecosystem stresses }->1.2 \text {. Ecosystem degradation } \\
\text { 2. Species Stresses }->2.1 \text {. Species mortality }\end{array}$}} \\
\hline & & & & \\
\hline & & & & \\
\hline \multirow{2}{*}{$\begin{array}{l}\text { 8. Invasive and other problematic species, genes \& } \\
\text { diseases }->8.1 \text {. Invasive non-native/alien } \\
\text { species/diseases }->8.1 .2 \text {. Named species } \\
\text { (Unspecified Rattus) }\end{array}$} & Ongoing & - & - & - \\
\hline & Stresses: & \multicolumn{3}{|c|}{$\begin{array}{l}\text { 2. Species Stresses }->2.3 \text {. Indirect species effects }-> \\
\text { 2.3.7. Reduced reproductive success }\end{array}$} \\
\hline \multirow{5}{*}{$\begin{array}{l}\text { 8. Invasive and other problematic species, genes \& } \\
\text { diseases }->8.1 \text {. Invasive non-native/alien } \\
\text { species/diseases }->8.1 .2 \text {. Named species (Rusa } \\
\text { timorensis) }\end{array}$} & Ongoing & - & - & - \\
\hline & Stresses: & \multirow{4}{*}{\multicolumn{3}{|c|}{$\begin{array}{l}\text { 1. Ecosystem stresses }->1.2 \text {. Ecosystem degradation } \\
\text { 2. Species Stresses }->2.1 \text {. Species mortality } \\
\text { 2. Species Stresses }->2.2 \text {. Species disturbance } \\
\text { 2. Species Stresses }->\text { 2.3. Indirect species effects }-> \\
\text { 2.3.7. Reduced reproductive success }\end{array}$}} \\
\hline & & & & \\
\hline & & & & \\
\hline & & & & \\
\hline
\end{tabular}

\section{Conservation Actions in Place}

(http://www.iucnredlist.org/technical-documents/classification-schemes) 


\begin{tabular}{|l|}
\hline Conservation Actions in Place \\
\hline In-Place Land/Water Protection and Management \\
\hline Occur in at least one PA: No \\
\hline Invasive species control or prevention: No \\
\hline In-Place Species Management \\
\hline Successfully reintroduced or introduced beningly: No \\
\hline Subject to ex-situ conservation: No \\
\hline
\end{tabular}

\title{
Conservation Actions Needed
}

(http://www.iucnredlist.org/technical-documents/classification-schemes)

\section{Conservation Actions Needed}

1. Land/water protection $->1.1$. Site/area protection

3. Species management $->$ 3.3. Species re-introduction $->$ 3.3.1. Reintroduction

\section{Research Needed}

(http://www.iucnredlist.org/technical-documents/classification-schemes)

\section{Research Needed}

1. Research $->1.2$. Population size, distribution \& trends

3. Monitoring $->$ 3.1. Population trends

\section{Additional Data Fields}

\author{
Distribution \\ Estimated area of occupancy $(\mathrm{AOO})\left(\mathrm{km}^{2}\right): 80$ \\ Continuing decline in area of occupancy (AOO): No \\ Extreme fluctuations in area of occupancy (AOO): No \\ Estimated extent of occurrence (EOO) $\left(\mathrm{km}^{2}\right): 757$ \\ Continuing decline in extent of occurrence (EOO): No \\ Extreme fluctuations in extent of occurrence (EOO): No \\ Number of Locations: 3 \\ Continuing decline in number of locations: No \\ Extreme fluctuations in the number of locations: No \\ Lower elevation limit (m): 1
}




\section{Distribution}

Upper elevation limit $(\mathrm{m}): 100$

\section{Population}

Number of mature individuals: 50-249

Continuing decline of mature individuals: Yes

Extreme fluctuations: No

Population severely fragmented: Yes

No. of subpopulations: 7

Extreme fluctuations in subpopulations: No

\section{Habitats and Ecology}

Continuing decline in area, extent and/or quality of habitat: Yes

Generation Length (years): 0 


\section{The IUCN Red List Partnership}

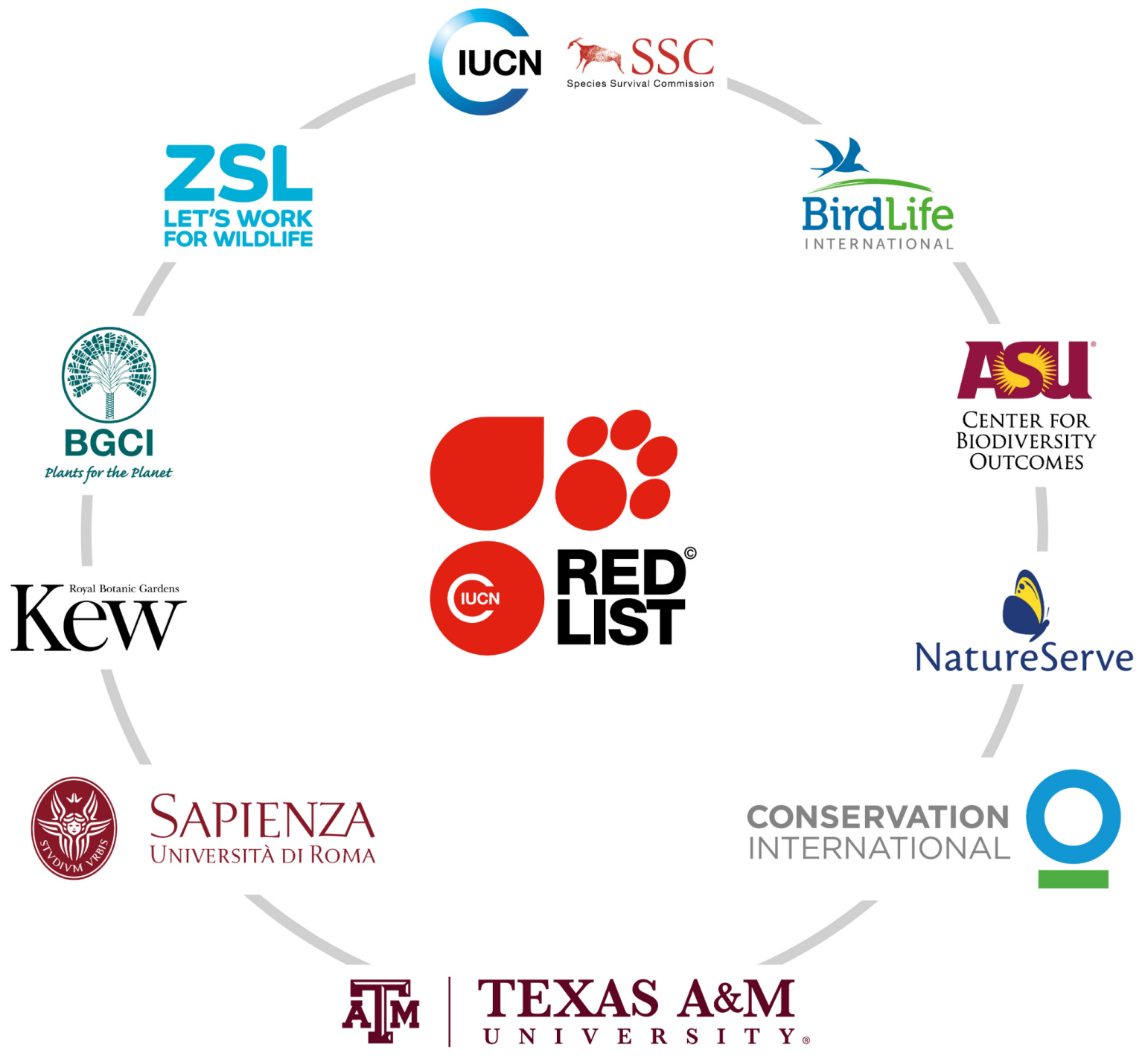

The IUCN Red List of Threatened Species ${ }^{\mathrm{TM}}$ is produced and managed by the IUCN Global Species Programme, the IUCN Species Survival Commission (SSC) and The IUCN Red List Partnership.

The IUCN Red List Partners are: Arizona State University; BirdLife International; Botanic Gardens Conservation International; Conservation International; NatureServe; Royal Botanic Gardens, Kew; Sapienza University of Rome; Texas A\&M University; and Zoological Society of London. 